\title{
Promoting Digital Change In Higher Education: Evaluating The Curriculum Digitalisation
}

\author{
Yelkin Diker Coskun, Yeditepe University, Turkey
}

\begin{abstract}
Technology, which forms part of all educational settings and curricula, is becoming an integral part of higher education too. Therefore, observations and interpretations from inside such settings are needed for a more realistic understanding. This study evaluates the information packages of the undergraduate programs of a university within the framework of a digital university, using program evaluation and document review of written curricula. The "Educational Connoisseurship and Criticism Model" was used for curriculum evaluation. The information packages of the undergraduate programs were generally found to reflect specific intentions concerning technology integration. However, these intentions have not yet become manifest in the learning outcomes of the programs. Thus, this study shows that, although technology has entered into all fields and programs, at least regarding learning outcomes, it has not found inadequate reciprocity within the processes of teaching and learning.
\end{abstract}

Keywords: Digital University; Curriculum Evaluation; Technology Integration

\section{INTRODUCTION}

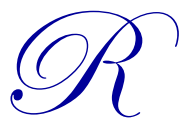

esearch indicates that today's technologies offer powerful capabilities for creating high-quality learning resources, such as visualization, simulation, games, interactivity, intelligent tutoring, collaboration, assessment and feedback (Expanding Evidence Approaches for Learning in a Digital World U.S. Department of Education Office of Educational Technology Report, 2013, p.7) Within the last decade, universities have experienced significant phases changes in making technology a transformative part of education, including efforts organize distance and online education (Parker, Lenhart, Moore, 2011). The effectiveness of a university can be evaluated from several program (for instance, its contribution to industry, developing creative individuals, contributing to political and social life). Major universities and research institutes in many countries are currently evaluating the effectiveness of their investments in technology. However, Keller argues that 'the larger question is whether the impressive investments in people will be sufficient to propel these countries to a global leadership position in innovations and economic development based on information technology' (2008 p.101), suggesting that expectations concerning higher education have been rapidly changing in the last two decades.

For many higher education programmes, extending learning opportunities so that they better meet learners' and employers' needs remains a major challenge. Redesigning learning to address the needs of lifelong learners has implications for pedagogy, business processes and information technology systems (JISC, Institutional Innovation Programme, cited Drysdale, 2012) Higher education has already experienced significant change driven by digital technology, resulting in heavy dependence on this technology. Research and scholarship are also highly dependent on information technology: for example, the use of computers to simulate physical phenomena, networks to link investigators in virtual laboratories or 'collaboratories', and digital libraries to provide scholars with access to knowledge resources (Duderstadt, 2003, p.39). All these efforts may be considered as a prerequisite for developing students as individuals with digital skills, and the capability to use digital skills flawlessly has recently become the primary quality sought in students graduating from universities. Possession of digital skills is considered as a prerequisite for innovation, creativity and efficiency in many industries. Universities are therefore trying to prepare 
their curricula on the basis of these skills, with technology and consequently digital skills no longer being considered as mere tools of education but important outcomes.

By 'digital literacy' we include skills for reading and interpreting the media in order to reproduce verbal and visual information, and the implementation and evaluation of new information received from the digital environment (Jones-Kavalier and Flannigan, 2006). Thus, the Educational Testing Service of America (2002) proposes the concept of 'digital competence'. Here, digital competence is defined as a combination of information, skills and attitudes for the safe and critical use of information society technologies for work, entertainment and communication purposes (Jun and Fun, 2011 p. 59). As part of the curriculum, developing digital literacy is not about being fashionable or merely trying to engage students in learning; it is about addressing the changing nature of subject knowledge and acknowledging that young people are going to need different kinds of skills, knowledge and understanding in order to develop their expertise. That is, developing digital literacy in subject teaching enables young people to be effective, competent, critical students of that subject in the digital age (Hauge and Payton, 2010, p. 12). "When technology is integrated throughout the curriculum, students will not only learn technology skills but also content knowledge" (Frei, Gammill and Irons, 2009).

If provision of support for digital literacy has now become a requirement for university curricula then it is necessary to ensure that the standards that constitute the concept of digital literacy are discussed within a clear framework so that curricula can be configured according to this framework. The literature on 21st century skills includes various frameworks, such as the Partnership for the 21st Century Skills Framework (2006), EnGauge Framework from Metiri/NCREL and the framework of American Association of College and Universities (Dede, 2010). In general terms, they share the concept of digital literacy. According to Kuo and others (2012), "Technological literacy involves a vision where each citizen has a degree of knowledge about the nature, behavior, power, and consequences of technology from a broad perspective. Inherently, it involves educational programs where learners become engaged in critical thinking as they design and develop products, systems, and environments to solve practical problems" (p.250).

New forms of literacy that have emerged in the new century (such as digital literacy, media literacy, information literacy, etc.), and the fact that with technological possibilities learning has become disconnected from time and space, make digital transformation inevitable for universities. This transformation may take place in three dimensions: administrative, educational and infrastructural. The purpose of the present study is to evaluate the program information packages created in one university on the basis of digital standards in the educational dimension of undergraduate programs, as per the digital transformation framework of education programs.

\section{METHOD}

This study used a descriptive case study design to examine higher education curricula. In this study, the packages of the undergraduate programs of Yeditepe University, Turkey, were evaluated within the frame of the digital university. The case study was chosen in order to "retain the holistic and meaningful characteristics of reallife events [including] organizational and managerial processes" (Yin, 1989, cited in Toledo, 2005). This study included a program evaluation study and document review of written curricula, in accordance with the "Educational Connoisseurship and Criticism Model developed by Eisner, who used the concept of connoisseurship for "promoting the ability to see a process or a work from multiple perspectives" (Eisner, 1988, cited in Alkin, 2013). This model has been applied in various areas of education, especially real-life curriculum extensions.

The key to developing knowledge within schooling and other educational settings (such as the family) is to create a varied and stimulating environment in which people become 'immersed'. Educators also need to encourage people to try make meaning; to 'read' (or conceptualize) the situation. This they do by constructing images 'derived from the material the senses provide' and refining 'the senses [as] a primary means for expanding ... [one’s own] consciousness’ (Eisner 1994, cited in Smith, 2005).

While technology has long been a part of educational settings and curriculum, digital technologies and skills have only recently started to become an integral part of higher education. Therefore, observing such settings from the inside could help us develop more realistic interpretations. According to Eisner (1985), teaching and learning, like 
art, require qualitative judgements, are often unpredictable, are non-prescriptive and can be performed with 'such skill and grace that for the student as well as for the teacher the experience can justifiably be called aesthetic' (Kelehear, 2010). According to Özkan and McKenzie (2006) the connoisseurship model has two major aspects in evaluating educational technologies: a holistic approach to the analysis and interpretation of data, and multiple perspectives towards the evaluative tasks. In this research all faculties and curricula were examined within such a holistic approach.

\section{Research Questions}

Program learning outcomes, course goals, course topics, and teaching and assessment methods for all the relevant program packages were taken into consideration as evaluation content. Regarding the evaluation criteria, a form was prepared (described in more detail in the section on data collection) according to ISTE standards.

The study's research question and sub-questions were defined as follows: 'What is the level of digital/technological competence of the undergraduate programs in Yeditepe University?'

1. What is the level of digital/technological competence of the general learning outcomes of the programs?

2. What is the level of digital/technological competence of the goals, contents, teaching methods and forms of assessment of the courses included in the programs?

\section{Sample}

Yeditepe University, founded in 1996 as a private University, carries out its academic mission through 12 faculties with 60 programs: Medicine, Dentistry, Pharmacy, Health Science, Law, Engineering and Architecture, Education, Arts and Sciences, Economics and Administrative Sciences, Commerce, Communication, and Fine Arts. Yeditepe University is the first foundation university in Turkey accredited by the Institutional Accreditation Program of the Association of European Universities (EUA) (http://www.yeditepe.edu.tr/about-yeditepe/generalinformation). In the 2013-2014 academic year, there was a total of 2,344 programs. The information packages of all of the undergraduate programs of Yeditepe University were included within the scope of the evaluation $(\mathrm{N}=21)$ although the number of courses provided in every program varied, a total of 565 courses were evaluated. Only fieldspecific courses for each faculty were taken into consideration.

Table 1. Distribution of faculty departments and number of courses

\begin{tabular}{lcc}
\hline \multicolumn{1}{c}{ Faculty } & Number of departments & Number of field-specific courses \\
\hline Pharmacy & 1 & 61 \\
Education & 3 & 59 \\
Arts and Sciences & 4 & 103 \\
Economics and Administrative Sciences & 4 & 91 \\
Fine Arts & 3 & 108 \\
Engineering and Architecture & 4 & 102 \\
Commerce & 2 & 41 \\
TOTAL & 21 & 565 \\
\hline
\end{tabular}

\section{Data Collection Tool and Evaluation Process}

The data collection tool used to evaluate the program information packages was based on ISTE (International Society for Technology in Education) 2007 standards. ISTE is considered the premier source for standards, performance indicators and outcomes for the assessment of ICT digital literacy competencies. It has been adopted by multiple institutions and K-12 commercial assessment developers (CETF ICT Digital Literacy Initiative, Consensus Document, 2008). ISTE asserts that merely using technology is no longer sufficient because today's students need to be capable of utilizing technology for analysing, learning and researching. The skills of the digital age are crucial for the students' preparation for working and general life, and their future contribution to society. ISTE lists its standards concerning the skills and knowledge that students need to attain in an increasingly global and digital world in seven categories: Creativity and Innovation, Communication and Collaboration, Research and Information Fluency, Critical Thinking, Problem Solving and Decision Making, Digital Citizenship, Technology Operations and Concepts (ISTE, 2007). 
The evaluation that was carried out at the level of program outcomes and courses was limited by the information provided in the program information packages. The evaluation attempted to identify the standards used in the evaluation form in the following categories of the program information packages:

- Embedding new skills and new literacies into program outcomes

- Curriculum and general aims of courses

- Course content

- Teaching methods

- Assessment methods

The above categories include the most basic elements that constitute a curriculum. Among ISTE standards, those that are relevant for the evaluation of program information packages were determined in order to prepare a "program evaluation rubric" according to ISTE standards. This included the six criteria concerning each of the topics of the program learning outcomes, course goals and course content, and one question concerning teaching and assessment methods. The rubric also included a total of 20 questions, evaluated at 3 levels (yes, partially, no). The evaluation was carried out in three stages. Firstly, a curriculum specialist and an instructional technology specialist compared the programs to ISTE standards. Second, the percentage compliance with the checklists for each criteria was determined. To ensure the reliability of the rubrics, the inter-rater agreement was checked, using the Weighted Kappa coefficient, where "Kappa Agreement $<0$ indicates less than chance agreement, 0.01-0.20 indicates slight agreement, $0.21-0.40$ indicates fair agreement, $0.41-0.60$ indicates moderate agreement, $0.61-0.80$ indicates substantial agreement, and 0.81-0.99 indicates almost perfect agreement" (Viera, Garrett, 2005 p. 362).

Table 2. Kappa Agreement coefficients in terms of ISTE standarts

\begin{tabular}{lccccc}
\hline & Program outcomes & Course goals & Course content & Teaching & Assessment \\
\hline Weighted Kappa coefficient & $80.3^{*}$ & $74.4^{*}$ & $60.0^{* *}$ & $72.2^{*}$ & $68.5^{*}$ \\
Course Number & 565 & 565 & 565 & 565 & 565 \\
\hline
\end{tabular}

$* *=\mathrm{p}<.01$

The weighted Kappa coefficients for the inter-rater reliability are presented in Table 2, which shows that the level of agreement between the two raters was substantial agreement except for the "course content" dimension.

\section{RESULTS}

Table 3 presents the results concerning the learning outcomes and teaching and assessment methods included in the information packages of 20 programs examined according to ISTE criteria.

As mentioned before in the data collection section, there were six questions regarding each program's learning outcomes, course goals and course contents. There was one question each for the teaching and assessment methods categories. 'Yes' answer was coded as '2', 'partially' as ' 1 ', and 'No' as ' 0 '. The total score for each category was then transformed into a percentile based on the minimum and maximum values, as shown in Table 3. 
Table 3. Technological competence levels of the categories in Program Information Packages.

\begin{tabular}{|c|c|c|c|c|c|}
\hline Program & $\begin{array}{c}\text { Integration Level } \\
\text { of the Outcomes of } \\
\text { the Program }\end{array}$ & $\begin{array}{c}\text { Integration Level } \\
\text { of the General } \\
\text { aims of courses }\end{array}$ & $\begin{array}{c}\text { Integration Level } \\
\text { of the Courses } \\
\text { Content }\end{array}$ & $\begin{array}{c}\text { Integration Level } \\
\text { of the Teaching } \\
\text { Methods }\end{array}$ & $\begin{array}{c}\text { Integration Level } \\
\text { of the Assessment } \\
\text { Methods }\end{array}$ \\
\hline $\begin{array}{l}\text { Faculty of Economics } \\
\text { and Administrative } \\
\text { Sciences }(\mathrm{N}=4) \\
\end{array}$ & $36 \%$ & $11 \%$ & $11 \%$ & $0 \%$ & $0 \%$ \\
\hline Business Administration & $42 \%$ & $25 \%$ & $25 \%$ & $0 \%$ & $0 \%$ \\
\hline Public Administration & $0 \%$ & $0 \%$ & $0 \%$ & $0 \%$ & $0 \%$ \\
\hline $\begin{array}{l}\text { Political Science and } \\
\text { International Relations }\end{array}$ & $42 \%$ & $0 \%$ & $0 \%$ & $0 \%$ & $0 \%$ \\
\hline Business Informatics & $58 \%$ & $17 \%$ & $17 \%$ & $0 \%$ & $0 \%$ \\
\hline $\begin{array}{l}\text { Faculty of Engineering } \\
\text { and Architecture } \\
(\mathrm{N}=3)\end{array}$ & $50 \%$ & $38 \%$ & $42 \%$ & $42 \%$ & $42 \%$ \\
\hline Computer Engineering & $67 \%$ & $42 \%$ & $58 \%$ & $50 \%$ & $50 \%$ \\
\hline Biomedical Engineering & $50 \%$ & $25 \%$ & $25 \%$ & $50 \%$ & $50 \%$ \\
\hline $\begin{array}{l}\text { Industrial and Systems } \\
\text { Engineering }\end{array}$ & $50 \%$ & $50 \%$ & $50 \%$ & $50 \%$ & $50 \%$ \\
\hline Food Engineering & $50 \%$ & $33 \%$ & $33 \%$ & $0 \%$ & $0 \%$ \\
\hline $\begin{array}{l}\text { Faculty of Pharmacy } \\
(\mathrm{N}=1)\end{array}$ & $50 \%$ & $42 \%$ & $42 \%$ & $50 \%$ & $50 \%$ \\
\hline $\begin{array}{l}\text { Faculty of Arts and } \\
\text { Sciences }(N=4)\end{array}$ & $28 \%$ & $26 \%$ & $27 \%$ & $25 \%$ & $0 \%$ \\
\hline $\begin{array}{l}\text { Translation and } \\
\text { Interpreting Studies }\end{array}$ & $25 \%$ & $33 \%$ & $33 \%$ & $50 \%$ & $0 \%$ \\
\hline Mathematics & $42 \%$ & $42 \%$ & $33 \%$ & $50 \%$ & $0 \%$ \\
\hline Sociology & $10 \%$ & $17 \%$ & $17 \%$ & $0 \%$ & $0 \%$ \\
\hline History & $33 \%$ & $10 \%$ & $25 \%$ & $0 \%$ & $0 \%$ \\
\hline $\begin{array}{l}\text { Faculty of Fine Arts } \\
(\mathrm{N}=3)\end{array}$ & $22 \%$ & $17 \%$ & $28 \%$ & $33 \%$ & $17 \%$ \\
\hline Plastic Arts & $0 \%$ & $17 \%$ & $17 \%$ & $0 \%$ & $0 \%$ \\
\hline Theatre & $33 \%$ & $17 \%$ & $33 \%$ & $50 \%$ & $50 \%$ \\
\hline Art Management & $33 \%$ & $17 \%$ & $33 \%$ & $50 \%$ & $0 \%$ \\
\hline $\begin{array}{l}\text { Faculty of Commerce } \\
(\mathrm{N}=2)\end{array}$ & $54 \%$ & $26 \%$ & $26 \%$ & $0 \%$ & $0 \%$ \\
\hline $\begin{array}{l}\text { Management } \\
\text { Information Systems }\end{array}$ & $58 \%$ & $42 \%$ & $42 \%$ & $0 \%$ & $0 \%$ \\
\hline International Finance & $50 \%$ & $10 \%$ & $10 \%$ & $0 \%$ & $0 \%$ \\
\hline $\begin{array}{l}\text { Faculty of Education } \\
(\mathrm{N}=3)\end{array}$ & $44 \%$ & $44 \%$ & $47 \%$ & $50 \%$ & $33 \%$ \\
\hline $\begin{array}{l}\text { Guidance and } \\
\text { Psychological } \\
\text { Counselling }\end{array}$ & $50 \%$ & $50 \%$ & $42 \%$ & $50 \%$ & $0 \%$ \\
\hline Teaching Mathematics & $58 \%$ & $50 \%$ & $50 \%$ & $50 \%$ & $50 \%$ \\
\hline $\begin{array}{l}\text { English Language } \\
\text { Teaching }\end{array}$ & $25 \%$ & $33 \%$ & $48 \%$ & $50 \%$ & $50 \%$ \\
\hline
\end{tabular}

\section{Results Concerning the First Sub-Question}

The first sub-question of the study was 'What is the level of digital/technological competence of the general learning outcomes of the programs?' Table 2 shows that the percentage departmental technological competence scores for the learning outcomes ranged between $58 \%$ and $25 \%$, except for Public Administration, which, at $0 \%$, can be assumed to be an outlier. This indicates that the programs are at least considering the objective of educating technologically literate individuals, capable of utilizing technology, both personally and professionally. For instance, the learning outcomes of the pharmacology program included the learning outcome of 'Keeping abreast of and being equipped to apply the fundamental pharmaceutical and health science principles which guide 
future developments in modern technology, and being able to share these experiences and skills with colleagues through participation in professional development education seminars'. This is clearly aimed at developing individuals that can effectively use modern technology in their professional development. Similarly, the following learning outcome of the Psychological Counselling and Guidance Program, 'Learning how to use internet and technology for accessing information, sharing information, professional development and data analysis', emphasized that effective use of technology and internet is an important part of professional development. In the mathematics program, on the other hand, the learning outcome concerning technology, 'Ability to learn, choose and use necessary information technologies', was limited to information technologies. Overall, the results indicate that technology in the university under study is considered as a forward-looking tool for ensuring life-long learning and professional development for those that graduate from these programs.

In some programs, technology is defined as one of the key professional competencies of the program. For instance, one of the learning outcomes of the Translation and Interpreting Studies program, 'Being able to use current translation technologies to do research and to reach resources', concerned a technology (translation technology) that is directly related with the students' future occupation. Learning outcomes configured in this way should have corresponding elements within the program.

\section{Results Concerning the Second Sub-Question}

The second sub-question of the study asked 'What is the level of digital/technological competence of the goals, contents, teaching methods and assessment ways of the courses included in the programs?' The way that these competences were included in the program goals can be clarified by examining three dimensions: course goals, contents, educational statuses and assessment. Analysis of the courses, as one of the most important tools for developing the qualities generally aimed for by the programs, in terms of the ISTE standards showed that they were not adequate (ranging from $50 \%$ down to $10 \%$ ) to develop individuals that can effectively utilize technology personally and professionally, as expressed in program learning outcomes. For example, although objectives such as 'Students should be able to effectively utilize computer and information technologies commonly-used in the social sciences' and 'Students will prove their understanding of the rapidly-evolving dynamics of national and global environments requires constant self-assessment, life-long learning, and the ability to formulate innovative solutions to maintain their personal and professional development' were included in the program outcomes of the department of political sciences, none of the courses in the program included any course goal or content to enable students to achieve these outcomes.

Similarly, the program outcomes of the department of Food Engineering included two goals related to digital competency: 'Usage of information technologies to solve food engineering problems and to design processes' and 'Appreciation of the need for lifelong learning, and for follow up on and application of developments in science and technology'. However, there was only one course related to the first of these digital competency goals, while there was no course or course content related to the second goal. Similar examples could be given for other departments.

\section{CONCLUSION}

In conclusion, the information packages of the undergraduate programs of Yeditepe University, examined here as a case, generally reflect intentions for integrating technology into educational programs. However, these intentions are not yet very manifested in the programs' curricula, particularly in the learning outcomes. Examination the categories of course goals, contents, teaching methods and assessment processes shows that they do not adequately support the goal of developing individuals that can effectively use technology as stated in program learning outcomes. Technology therefore needs to be utilized as a more effective educational tool, particularly in the creation of course contents and configuration of the learning process. Although it would be unrealistic to expect the immediate and direct inclusion of the current technologies specific to every field and occupation in the related education programs (other than in a few exceptional cases), at least the educational processes that aim to create awareness of new technologies should be configured according to clear standards, while innovative learning resources should also be developed. 
In order for a university curriculum to have a continuously developing structure capable of fulfilling today's changing needs, it is necessary to ensure that it is technologically friendly and interdisciplinary. At this point, big data and new data analysis techniques can help us in curriculum mapping. 'Big data denotes datasets that are large, complex, and difficult to store, search, share, analyse, and visualize using commonly available analytical tools and methods' (Expanding Evidence Approaches for Learning in a Digital World U.S. Department of Education Office of Educational Technology Report, 2013, p.7). Utilization of digital analysis and planning techniques by universities as tools for regulating education would be useful. It should also be kept in mind that 'curriculum design is not carried out in isolation but forms part of an iterative cycle of market research, planning, development, implementation and review. However, within some institutions, there may be barriers to designing curricula that meet the needs of lifelong learners' (Drysdale, 2012, p. 20).

Finally, as indicated by the results of this study, although technology has entered into all fields and programs, at least regarding learning outcomes, it is not yet adequately represented in the process of learning Therefore, it needs to be ensured that curricula based on digital literacy competencies prepared according to clear standards are established and evaluated. If such curricula that are founded on digital literacy are established then academic competencies and the quality of learning processes will improve. This would allow digital curricula to be revised repeatedly, quickly and economically. It would be valuable for a future study of this issue to make an indepth evaluation by interviewing faculty members and students regarding the way their actual courses progress.

\section{REFERENCES}

CETF- ICT (2008). California ICT Digital Literacy Policy Framework. Initiative Consensus Document. Retrieved from: http://www.ictliteracy.info/rf.pdf/California\%20\%20ICTPolicy\%20Framework.pdf

Dede, C., (2010). Comparing Frameworks for 21 st Century Skills. In J. Bellanca \& R. Brandt, Eds, 21st Century Skills, pp. 51-76. Bloomington, IN: Solution Tree Press.

Duderstadt, J. J., 2003. Preparing for the Revolution: The Future of the University in the Digital Age. In Weber, Luc E; Hirsch, Werner Z. (Ed.). As the Walls of Academia Are Tumbling Down. London: Economica.

Eisner, E.W. (1988). The Roots Of Connoisseurship And Criticism A Personal Journey. http://www.sagepub.com/upm-data/47602_alkin2e ch31.pdf In Alkin, M. C. (Ed.). (2012). Evaluation roots: A Wider Perspective of Theorists' Views and Influences (2nd ed.). Thousand Oaks, CA: Sage.

Frei, S. A. Gammill, S. Irons. (2009). Integrating technology into the curriculum. California, USA : Shell Education.

Hague, C., S. Payton, 2010. Digital literacy across the curriculum. Report. Futurelab Retrieved from: http://www2.futurelab.org.uk/resources/documents/handbooks/digital_literacy.pdf

ISTE-International Society for Technology in Education (2007). The national educational technology standards and performance indicators for students. Retrieved from: http://www.iste.org/docs/pdfs/nets-sstandards.pdf?sfvrsn=2

JISC (2012). Learning in a Digital Age. Report. Retrieved from: http://www.jisc.ac.uk/media/documents/programmes/elearning/Digilifelong/Lifelong\%20Learning\%20acce ssible\%20PDF.pdf.

Jones-Kavalier, B. R., \& Flannigan, S.L. (2006). Connecting the digital dots: Literacy on the 21st century. EDUCAUSE Quarterly , 29 (2), 8-10.

Jun, F., Pow, J. (2011) Fostering Digital Literacy through Web-based Collaborative Inquiry Learning - A Case Study, Journal of Information Technology Education: Innovations in Practice, v. 10.

Viera, J. A., Garrett, J., M. (2005)Understanding Interobserver Agreement: The Kappa Statistic. Family Medicine. Research Series. Retrieved from: http://www1.cs.columbia.edu/ julia/courses/CS6998/Interrater_agreement.Kappa_statistic.pdf

Kelehear, Z. (2008) Instructional leadership, connoisseurship and critique: using an arts- based approach to extend conversations about teaching, International Journal of Leadership in Education: Theory and Practice, 11:3, 239-256, DOI: $10.1080 / 13603120701721821$

Keller, H. Kenneth, 2008. From Here to There in Information Technology: The Complexities of Innovation. American Behavioral Scientist. Vol. 52 (1), p. 97-106.

Kuo, L.-H., H. M., Wei, L.M. Chen, M.C., Wang, M. K., Ho, H. J., Yang (2012) An Evaluation Model of Integrating Emerging Technology into Formal Curriculum. International Journal Of Education and Information Technologies. Issue 3, Vol 6, p. 250-259. Retrieved from: 
http://naun.org/main/NAUN/educationinformation/16-288.pdf

Ozkan, Betul C.; McKenzie, Barbara K. (2006) Online Submission, Paper presented at the Annual Meeting of Eastern Educational Research Association (Hilton Head, SC, Feb 22-25) Retrieved from: http://files.eric.ed.gov/fulltext/ED491403.pdf

Parker, K., Lenhart, A., \& Moore, K., (2011) The digital revolution and higher education: College presidents, public differ on value of online learning. Retrieved from: http://www.pewinternet.org/ /media//Files/Reports/2011/PIP-Online-Learning.pdf

Smith, M. K. (2005) 'Elliot W. Eisner, connoisseurship, criticism and the art of education' The encyclopaedia of informal education, Retrieved from: www.infed.org/thinkers/eisner.htm.

Taylor, P., K. Parker, A. Lenhart, E. Patten, (2011) The Digital Revolution and Higher Education. Report. Retrieved from: http://www.pewinternet.org/ /media//Files/Reports/2011/PIP-Online-Learning.pdf

Toledo, C. (2005) A five-stage model of computer technology integration into teacher education curriculum. Contemporary Issues in Technology and Teacher Education, 5(2), 177-191.

U.S. Department of Education, Office of Educational Technology (2013) Expanding Evidence Approaches for Learning in a Digital World, Washington, D.C. Retrieved: http://www.ed.gov/edblogs/technology/files/2013/02/Expanding-Evidence-Approaches.pdf. 